\title{
RETRACTED ARTICLE: Hydrologic evaluation on the ERA- Interim output using observed river discharge data
}

\author{
L. A. Djiotang Tchotchou ${ }^{1}$ - A. Tompkins ${ }^{2} \cdot$ F. Mkankam Kamga ${ }^{1}$
}

Received: 13 September 2013/ Accepted: 26 March 2014/Published online: 22 April 2014

(C) The Author(s) 2014. This article is published with open access at Springerlink.com

This article is retracted at the request of the Editors-inChief per the Committee on Publication Ethics (COPE) guidelines on plagiarism. The article shows considerable overlap with previously published articles without proper citation. Moreover, the manuscript was submitted without the knowledge and consent of the second author. The Editors of Applied Water Science take issues of research and publication misconduct seriously in order to preserve the integrity of the academic record. Our apologies are extended to the readers that this was not discovered before publication.

The online version of this article contains the full text of the retracted article as electronic supplementary material.

Open Access This article is distributed under the terms of the Creative Commons Attribution License which permits any use, distribution, and reproduction in any medium, provided the original author(s) and the source are credited.
Electronic supplementary material The online version of this article (doi:10.1007/s13201-014-0183-9) contains supplementary material, which is available to authorized users.

L. A. Djiotang Tchotchou

angennes@yahoo.fr

1 Laboratory for Environmental Modelling and Atmospheric Physics, Department of Physics, Faculty of Sciences, University of Yaoundé 1, Yaounde, Cameroon

2 Physics of Weather and Climate Group, Earth System Physics Section, International Centre for Theoretical Physics, Trieste, Italy 